\title{
MANIHOT ESCULENTA (EUPHORBIACEAE), A NEW ALIEN SPECIES IN ITALY
}

\author{
Adriano STINCA ${ }^{1, *}$, Giuseppe D'AURIA ${ }^{2} \&$ \\ Riccardo MOTTI ${ }^{1}$
}

\begin{abstract}
In the present work the presence of Manihot esculenta Crantz is reported for the first time for Italy and Europe, a neophyte native to South America: ecology and invasive status are presented.

Keywords: alien status, exotic species, invasiveness, vascular flora.

Izvleček

V članku poročamo o prvem pojavljanju vrste Manihot esculenta Crantz, neofita iz Južne Amerike, v Italiji in Evropi in predstavljamo njegovo ekologijo in invazivni status.

Ključne besede: tujerodna vrsta, eksotična vrsta, invazivnost, cevnice.
\end{abstract}

\section{INTRODUCTION}

During floristic research in Campania region (Southern Italy, July 2013), one population referred the genus Manihot Mill. was found. The genus is not reported in the European floras (e.g. Tutin 1968, Chrtek \& Křísa 1982, Davis 1982, 1988, Lid 1987, Benedí 1997, Polatschek 1999, Frederiksen et al. 2006, Stace 2010), and Italian floras and checklist (e.g. Fiori 1926, Zangheri 1979, Pignatti 1982, Conti et al. 2005, 2007, Celesti-Grapow et al. 2009), but Iberite \& Iamonico (in press) have recently discovered a naturalized population of Manihot grahamii Hook. in Lazio region (Central Italy).

In this paper Manihot esculenta Crantz. (vernacular name Cassava, Tapioca or Yuca) (Euphorbiaceae) is reported for the first time in Italy and Europe. Its invasive status and ecological notes are provided.

\section{MATERIALS AND METHODS}

The identification of the species was made on the basis of the description by Standley (1937),
Standley \& Steyermark (1949), Macbride (1951), and Rogers \& Appan (1973). The protologue by Crantz (1766) was also examined. The collected specimen are kept in Herbarium Porticense (PORUN - acronym according to Thiers, 2011). Italian literature was examined to detect previous indications of the species in Italy and in Campania (e.g. Fiori 1926, Pignatti 1982, Conti et al. 2005, 2007, Celesti-Grapow et al. 2010, Stinca et al. 2012a, 2013). The status of naturalization was defined according to Richardson et al. (2000) and Pyšek et al. (2004).

\section{RESULTS AND DISCUSSION}

Manihot esculenta (lectotype designated by Rogers \& Appan, 1973: fig. 4 and 5 in Merian, 1726) is a species native to the South America, probably from Peru and Brazil (e. g. Allem 1994, Olsen \& Schaal 1999), it is extensively cultivated as annual crop in tropical and subtropical regions for its edible starchy tuberous root. In Europe it is rarely grown as ornamental plant (pers. obs.).

Manihot esculenta was collected in the Royal Park of Portici (Campania region, Southern It-

\footnotetext{
${ }^{1}$ Dipartimento di Agraria, Università di Napoli Federico II, via Università 100, 80055-Portici (Naples), Italy

${ }^{2}$ Servizio Fitosanitario Regionale, Regione Campania (SeSIRCA), via Don Bosco 9/E, 80141-Naples, Italy

* E-mail: adriano.stinca@unina.it
} 
aly). The area is situated on the Bay of Naples on the southwestern foothills of Mt. Vesuvius, at $60 \mathrm{~m}$ a.s.l. (WGS84 coordinates: 33T $444717 \mathrm{E}$ $4518087 \mathrm{~N}$ ). Climate is Mediterranean type that is characterized by an average annual temperature of $18.0^{\circ} \mathrm{C}$, average annual rainfall of 929.1 $\mathrm{mm}$, and a summer period of drought which lasts from June to August (Stinca \& Motti 2009).

Manihot esculenta was found in a natural wood of holm oak (that characterizes the Royal Park) and can be referred to Quercetalia ilicis Br.-Bl. ex Molinier 1934. Frequent taxa are: Quercus ilex L. subsp. ilex, Acanthus mollis L. subsp. mollis, Hedera helix L. subsp. helix, Fraxinus ornus L. subsp. ornus, Parietaria judaica L., Rubus ulmifolius Schott, Sambucus nigra L., Celtis australis L. subsp. australis, Arum italicum Mill. subsp. italicum, Ruscus aculeatus L., Euphorbia platyphyllos L. subsp. platyphyllos, Piptatherum miliaceum (L.) Coss. subsp. miliaceum, Silene latifolia Poir. subsp. alba (Mill.) Greuter \& Burdet, Laurus nobilis L., Ballota nigra L. subsp. meridionalis (Bég.) Bég., Chelidonium majus L., Viola alba Besser subsp. dehnhardtii (Ten.) W. Becker, Aristolochia sempervirens L., and Calystegia silvatica (Kit.) Griseb. Furthermore, ruderal (Chenopodium album L. subsp. album, Mercurialis annua L., Artemisia vulgaris L. and Solanum nigrum L.) and alien taxa (Phytolacca americana L., Ehrharta erecta Lam., Erigeron sumatrensis Retz., Oxalis incarnata L., Salpichroa origanifolia (Lam.) Thell., Solanum chenopodioides Lam., Oxalis latifolia Kunth and seedlings of Phoenix canariensis Hort ex Chabaud) occur, highlighting the human impact on the area. Really, the Royal Park of Portici is placed within the urban continuum of the towns Portici and Ercolano (province of Naples), and its flora has a high percentage of exotic species (Stinca \& Motti 2009, Motti \& Stinca 2011, Stinca et al. 2012a, 2012b, 2013).

The Manihot esculenta population consists of 22 specimens with an average diameter of 1.7 $\mathrm{cm}$, the largest $2.1 \mathrm{~cm}$. One specimen of Manihot esculenta is grown in the Botanical Gardens far from the area about $300 \mathrm{~m}$ and surrounding by high walls. According to Richardson et al. (2000) and Pyšek et al. (2004), Manihot esculenta can be considered a casual alien plant in Italy, because it does not form self-replacing populations (pers. obs.). Therefore, its persistence relies on repeated introductions. However, because of the length of the reproductive cycle of this species further field investigations are necessary for the proper attribution of the invasive status.

\section{Specimina visa}

ITALY: Campania, Portici al Parco Reale (Napoli), WGS84 33T 444717 E 4518087 N, margine lecceta, $60 \mathrm{~m}$ a.s.l., 14-07-2013, leg. A. Stinca, det. A. Stinca et R. Motti (PORUN).

\section{REFERENCES}

Allem, A.C. 1994: The origin of Manihot esculenta Crantz (Euphorbiaceae). Genetic Resources and Crop Evolution 41 (3): 133-150.

Benedí, C. 1997: Euphorbiaceae. In: Castroviejo, S., Aedo, C., Benedí, C., Laínz, M., Muñoz Garmendia, F., Nieto Feliner, G. \& Paiva, J. (eds.), Flora iberica: plantas vasculares de la Península Ibérica e Islas Baleares 8. Real Jardín Botánico, CSIC, Madrid, pp. 190-297.

Celesti-Grapow, L., Alessandrini, A., Arrigoni, P.V., Banfi, E., Bernardo, L., Bovio, M., Brundu, G., Cagiotti, M.R., Camarda, I., Carli, E., Conti, F., Fascetti, S., Galasso, G., Gubellini, L., La Valva, V., Lucchese, F., Marchiori, S., Mazzola, P., Peccenini, S., Poldini, L., Pretto, F., Prosser, F., Siniscalco, C., Villani, M.C., Viegi, L., Wilhalm, T. \& Blasi, C. (eds.) 2009: Inventory of the non-native flora of Italy. Plant Biosystems 143 (2): 386-430.

Celesti-Grapow, L., Pretto, F., Carli, E. \& Blasi, C. (eds.). 2010: Flora alloctona e invasiva d'Italia. Casa Editrice Università La Sapienza, Roma, 208 pp.

Chrtek, J. \& Kř́sa, B. 1982: Euphorbiaceae Juss. In: Futák, J. \& Bertová, L., Flóra Slovenska 3. VEDA, vydavatel'stvo Slovenskej akadémie vied, pp. 406-462.

Conti, F., Abbate, G., Alessandrini, A. \& Blasi, C. (eds.). 2005: An Annotated Checklist of the Italian Vascular Flora. Palombi Editori, Roma, $420 \mathrm{pp}$.

Conti, F., Alessandrini, A., Bacchetta, G., Banfi, E., Barberis, G., Bartolucci, F., Bernardo, L., Bonacquisti, S., Bouvet, D., Bovio, M., Brusa, G., Del Guacchio, E., Foggi, B., Frattini, S., Galasso, G., Gallo, L., Gangale, C., Gottschlich, G., Grünanger, P., Gubellini, L., Iiriti, G., Lucarini, D., Marchetti, D., Moraldo, B., Peruzzi, L., Poldini, L., Prosser, F., Raffaelli, M., Santangelo, A., Scassellati, E., Scortegagna, S., Selvi, F., Soldano, A., Tinti, D., Ubaldi, D., Uzunov, D. \& Vidali, M. 2007: Integra- 
zioni alla checklist della flora vascolare italiana. Natura Vicentina, 10 (2006): 5-74.

Crantz, H.J.N. von 1766: Insitutiones Rei Herbariae juxta nutum natur naturae digestae ex habitu 1. I.P. Kravs, p. 167.

Davis, P.H. (ed.) 1982: Flora of Turkey and East Aegean Islands 7. Edinburgh University Press, Edinburgh, pp. 566-630.

Davis, P.H. (ed.) 1988: Flora of Turkey and East Aegean Islands 10 (supplement). Edinburgh University Press, Edinburgh, pp. 213-214.

Fiori, A., 1926: Nuova Flora Analitica d'Italia contenente la descrizione delle piante vascolari indigene, inselvatichite e largamente coltivate in Italia 2. Tipografia di M. Ricci, Firenze, pp. 167-190.

Frederiksen, S., Rasmussen, F.N. \& Seberg, O. 2006: Dansk flora. Gyldendal, København, pp. 366-369.

Iberite, M \& Iamonico, D. in press. Manihot grahamii Hook. (Euphorbiaceae) a new alien species for the Eurasian area with notes on its taxonomy, morphology and ecology. Acta Botanica Croatica.

Lid, J. 1987: Norsk, svensk, finsk flora. De Norske Samlaget, Oslo, pp. 304-306.

Macbride, J.F. 1951: Flora of Peru. Field Museum of Natural History. Botanical Series 13, part. IIIA, number 1: 168-173.

Merian, M.S. 1726: Dissertatio de generatione et metamorphosibus insectorum Surinamensium. Hagae Comitum, apud Petrum Gosse, p. 4.

Motti, R. \& Stinca, A. 2011: Analysis of the biodeteriogenic vascular flora at the Royal Palace of Portici in southern Italy. International Biodeterioration \& Biodegradation 65 (8): 1256-1265.

Olsen, K.M. \& Schaal, B.A. 1999: Evidence on the origin of cassava: Phylogeography of Manihot esculenta. Proocedings of the National Academy of Sciences of the United States of America 96: 5586-5591.

Pignatti, S. 1982: Flora d'Italia 2. Edagricole, Bologna, pp. 26-50.

Polatschek, A. 1999: Flora von Nordtirol, Osttirol und Vorarlberg 2. Tiroler Landesmuseum Ferdinandeum, Innsbruck, pp. 786-802.

Pyšek, P., Richardson, D.M., Rejmánek, M., Webster, G.L., Williamson, M. \& Kirschner, J. 2004: Alien plants in checklist and floras: towards better communication between taxonomists and ecologists. Taxon 53 (1): 131-143.

Richardson, D.M., Pyšek, P., Rejmánek, M., Barbour, M.G., Panetta, F.D. \& West, C.J. 2000:
Naturalization and invasion of alien plants: concept and definitions. Diversity and Distributions 6 (2): 93-107.

Rogers, D.J. \& Appan, S.G. 1973: Flora Neotropica. Monograph No. 13. Manihot Manihotoides (Euphorbiaceae), pp. 25-34.

Stace, C. 2010: New flora of the British Isles. Cambridge University Press, Cambridge, pp. 306-311.

Standley, P.C. \& Steyermark, J.A. 1949: Flora of Guatemala. Fieldiana: botany 24 (6): 133-138.

Standley, P.C. 1937: Flora of Costa Rica. Part II. Field Museum of Natural History. Botanical Series 18 (2): 615-616.

Stinca, A., D'Auria \& G., Motti, R. 2012a: Integrazioni alla flora vascolare aliena della Campania (Sud Italia). Informatore Botanico Italiano 44 (2): 287-293.

Stinca, A., D'Auria, G. \& Motti, R. 2012b: Sullo status invasivo di Bidens bipinnata, Phoenix canariensis, Pistia stratiotes e Tradescantia fluminensis in Campania (Sud Italia). Informatore Botanico Italiano 44 (2): 295-299.

Stinca, A., D'Auria, G., Salerno \& G., Motti, R. 2013: Ulteriori integrazioni alla flora vascolare aliena della Campania (Sud Italia). Informatore Botanico Italiano 45 (1): 71-81.

Stinca, A. \& Motti, R. 2009: The vascular flora of the Royal Park of Portici (Naples, Italy). Webbia 64 (2): 235-266.

Thiers, B. 2011: Index Herbariorum: A global directory of public herbaria and associated staff. New York Botanical Garden's Virtual Herbarium. Available from http://sweetgum.nybg. org/ih/ [accessed: 10 Feb 2014].

Tutin, T.G (ed.) 1968: Euphorbiaceae. In: Tutin, T.G., Heywood, V.H., Burges, N.A., Moore, D.M., Valentine, D.H., Walters, S.M. \& Webb, D.A. (eds.), Flora Europaea 2. Cambridge University Press, Cambridge, pp. 211-226.

Zangheri, P., 1976: Flora Italica 1. CEDAM, Padova, pp. 359-371. 